\title{
Hypokalemia in the setting of acute kidney injury and non-anion gap metabolic acidosis
}

Nuno Moreira Fonseca, Patrícia Alves, David Navarro, João Sousa, Fernando Nolasco

Nephrology Department, Centro Hospitalar Universitário de Lisboa Central, Hospital Curry Cabral, Lisbon, Portugal

\section{CASE PRESENTATION}

We present a case of a 48-year-old female with past medical history of well-controlled hypertension who was diagnosed with Ewinglike sarcoma, with abdominal wall involvement and pulmonary metastatic lesions. At time of diagnosis kidney function was normal (estimated glomerular filtration rate [eGFR] of $87 \mathrm{ml} / \mathrm{min} / 1.73 \mathrm{~m}^{2}$ ), and ionogram and urinalysis were unremarkable.

The patient was started on chemotherapy - eight courses of VID (vincristine $1.4 \mathrm{mg} / \mathrm{m} 2$ [2mg], ifosfamide $3000 \mathrm{mg} / \mathrm{m} 2$ [6g], and doxorubicin $20 \mathrm{mg} / \mathrm{m} 2$ [40mg]) and mesna. A favorable response was obtained with lesion size reduction, allowing for surgery to remove the primary lesion. Adjuvant chemotherapy followed with VAI (vincristine $1.4 \mathrm{mg} / \mathrm{m} 2$ [2mg], actinomycin $0.75 \mathrm{mg} / \mathrm{m} 2$ [1.5mg], and ifosfamide $3000 \mathrm{mg} / \mathrm{m} 2[6 \mathrm{~g}])$.

Two weeks after the second cycle of VAI she developed AKIN 2 acute kidney injury. Laboratory findings included hypokalemia, hypophosphatemia, hypouricemia, normal blood glucose levels and new onset proteinuria within the tubular range. An arterial blood gas analysis revealed a non-anion gap metabolic acidosis. Laboratory results are shown in table 1 . Renal ultrasound excluded the presence of kidney stones or obstruction. Urine anion gap was negative. Urinary sediment showed renal tubular epithelial cells.

\section{WHAT IS THE ORIGIN OF THE PATIENT'S METABOLIC ACIDOSIS?}

Non-anion gap metabolic acidosis results from a loss of bicarbonate or impaired renal acid excretion. Loss of bicarbonate can occur in multiple clinical settings: loss of bicarbonate-rich fluid such as in diarrhea, or pancreatic or biliary drainages, or through renal losses in the setting of proximal renal tubular acidosis (RTA). Impaired acid excretion occurs in the setting of distal renal tubular acidosis. ${ }^{1}$

Our patient had no history of diarrhea or other bicarbonate-rich fluid; thus, the next step was to consider the diagnosis of possible RTA.

Table 1

Blood and Urine tests

\begin{tabular}{|c|c|c|c|c|c|c|c|c|c|c|c|}
\hline \multicolumn{3}{|c|}{ Blood } & \multicolumn{3}{|c|}{24 hours Urine } & \multicolumn{3}{|c|}{ Urine Dipstick Test } & \multicolumn{3}{|c|}{ Arterial Blood Gas } \\
\hline Test & Results & $\begin{array}{c}\text { Reference } \\
\text { Range }\end{array}$ & Test & Results & $\begin{array}{c}\text { Reference } \\
\text { Range }\end{array}$ & Test & Results & $\begin{array}{c}\text { Reference } \\
\text { Range }\end{array}$ & Test & Results & $\begin{array}{c}\text { Reference } \\
\text { Range }\end{array}$ \\
\hline $\begin{array}{l}\text { Serum } \\
\text { creatinine }\end{array}$ & $1.9 \uparrow$ & $\begin{array}{c}0.57-1.11 \\
\mathrm{mg} / \mathrm{dL}\end{array}$ & $\begin{array}{l}\text { Urinary } \\
\text { sodium }\end{array}$ & $226 \uparrow$ & $\begin{array}{l}40.0-220 \\
\mathrm{mEq} / 24 \mathrm{~h}\end{array}$ & $\mathrm{pH}$ & 7 & $5-8$ & $\mathrm{pH}$ & 7.309 & $7.35-7.45$ \\
\hline Serum urea & 25 & $\begin{array}{c}15.0-40.0 \\
\mathrm{mg} / \mathrm{dL}\end{array}$ & $\begin{array}{l}\text { Urinary } \\
\text { potassium }\end{array}$ & 66.3 & $\begin{array}{c}25-125 \\
\mathrm{mEq} / 24 \mathrm{~h}\end{array}$ & $\begin{array}{l}\text { Urine specific } \\
\text { gravity }\end{array}$ & 1.012 & $1.002-1.030$ & pO2 & 95.6 & 35-45 mmHg \\
\hline $\begin{array}{l}\text { Serum } \\
\text { sodium }\end{array}$ & 144 & $\begin{array}{c}136-145 \\
\mathrm{mEq} / \mathrm{L}\end{array}$ & $\begin{array}{l}\text { Urinary } \\
\text { chloride }\end{array}$ & 201 & $\begin{array}{c}110-50 \\
\mathrm{mEq} / 24 \mathrm{~h}\end{array}$ & Nitrites & Negative & & pCO2 & 35.2 & 80-100 mmHg \\
\hline $\begin{array}{l}\text { Serum } \\
\text { potassium }\end{array}$ & $2.5 \downarrow$ & $\begin{array}{c}3.50-5.10 \\
\mathrm{mEq} / \mathrm{L}\end{array}$ & $\begin{array}{l}\text { Urinary } \\
\text { glucose }\end{array}$ & $28435 \uparrow$ & $<500 \mathrm{mg} / 24 \mathrm{~h}$ & Proteins & 50 & $\mathrm{mg} / \mathrm{dL}$ & HCO3- & 18 & $22-26 \mathrm{mEq} / \mathrm{L}$ \\
\hline $\begin{array}{l}\text { Serum } \\
\text { chloride }\end{array}$ & $117 \uparrow$ & $\begin{array}{c}98.0-107 \\
\mathrm{mEq} / \mathrm{L}\end{array}$ & $\begin{array}{l}\text { Urinary uric } \\
\text { acid }\end{array}$ & $753.2 \uparrow$ & $\begin{array}{c}250-750 \mathrm{~m} \\
\mathrm{mg} / 24 \mathrm{~h}\end{array}$ & Glucose & $500 \uparrow$ & $\mathrm{mg} / \mathrm{dL}$ & $\mathrm{Na}$ & 144 & $\begin{array}{c}136-146 \\
\mathrm{mEq} / \mathrm{L}\end{array}$ \\
\hline $\begin{array}{l}\text { Serum } \\
\text { phosphate }\end{array}$ & $1.7 \downarrow$ & $\begin{array}{c}2.30-4.70 \\
\mathrm{mg} / \mathrm{dL}\end{array}$ & $\begin{array}{l}\text { Urinary } \\
\text { proteins }\end{array}$ & $2065 \uparrow$ & $<300 \mathrm{mg} / 24 \mathrm{~h}$ & $\begin{array}{l}\text { Ketone } \\
\text { bodies }\end{array}$ & Negative & & $\mathrm{K}$ & 2.4 & 3.5-4.5 mEq/L \\
\hline \multirow[t]{3}{*}{$\begin{array}{l}\text { Serum uric } \\
\text { acid }\end{array}$} & $1.8 \downarrow$ & $\begin{array}{c}2.60-6.00 \\
\mathrm{mg} / \mathrm{dL}\end{array}$ & $\begin{array}{l}\text { Urinary } \\
\text { albumin }\end{array}$ & $382 \uparrow$ & $<30 \mathrm{mg} / 24 \mathrm{~h}$ & Hemoglobin & 0.03 & $\mathrm{mg} / \mathrm{dL}$ & $\mathrm{Cl}$ & $117 \uparrow$ & 98-106 mEq/L \\
\hline & & & $\begin{array}{l}\text { Urinary } \\
\text { creatinine }\end{array}$ & 920 & $\begin{array}{c}710- \\
1650 \mathrm{mg} / 24 \mathrm{~h}\end{array}$ & $\begin{array}{l}\text { Red blood } \\
\text { cells }\end{array}$ & 12 & $<25 / \mathrm{mm}^{3}$ & Anion Gap & 9 & $8-16$ \\
\hline & & & & & & $\begin{array}{l}\text { White blood } \\
\text { cells }\end{array}$ & $203 \uparrow$ & $<22 / \mathrm{mm}^{3}$ & & & \\
\hline
\end{tabular}


In proximal RTA proximal bicarbonate reabsorptive capacity is reduced, leading to bicarbonate loss in the urine until serum bicarbonate concentration has fallen to a level low enough to allow all the filtered bicarbonate to be reabsorbed. In distal RTA there is impaired distal acidification, shown by reduced urinary ammonium excretion. Hypokalemia is an accompanying feature of both distal and proximal RTA. ${ }^{2}$

In physiological setting, metabolic acidosis leads to an increased need for ammonium excretion. Direct urinary ammonium excretion measurement is difficult and is unavailable in most clinical laboratories. Since urinary ammonium excretion is accompanied by the anion chloride, changes in the urine anion gap (UAG $\left.=\mathrm{Na}^{+}+\mathrm{K}^{+}-\mathrm{Cl}^{-}\right)$will reflect ammonium excretion abnormalities. A negative urine anion gap (meaning increased urine chloride) can be used as evidence of increased ammonium excretion. The inability to excrete ammonia will be shown by a negative urine anion gap, and favors the diagnosis of distal RTA. However, there is conflicting evidence about the existence of impaired distal acidification in proximal RTA, and these patients may present a positive or slightly positive UAG. ${ }^{3}$

Other features can be helpful in the differentiation between proximal and distal RTA. In distal RTA, serum bicarbonate concentration usually stabilizes at a level less than $10 \mathrm{mEq} / \mathrm{L}$, while in proximal RTA it is usually between 16 and $20 \mathrm{mEq} / \mathrm{L}$. In proximal RTA, despite the loss of proximal bicarbonate reabsorption, distal renal tubule segments maintain some capacity to reabsorb bicarbonate. When the serum bicarbonate is low, most of the filtered bicarbonate can be reabsorbed and distal acidification then proceeds normally. ${ }^{3}$

In addition to the difference of serum bicarbonate concentration, proximal RTA most commonly occurs in association with other defects in proximal tubular function, such as impaired reabsorption of phosphate, glucose, uric acid, and amino acids. This form of generalized proximal tubular dysfunction is known as Fanconi syndrome. ${ }^{4}$

Our patient presented a non-anion gap metabolic acidosis with a serum bicarbonate of $18 \mathrm{mEq} / \mathrm{L}$, hypophosphatemia, hypouricemia, with renal wasting of phosphate, glucose, uric acid, thus suggesting the diagnosis of proximal RTA.

\section{WHAT IS THE MOST LIKELY ETIOLOGY?}

Proximal tubular acidosis can occur in the setting of genetic diseases or acquired causes. Our patient presented with recent onset metabolic acidosis, making hereditary causes of proximal tubular acidosis unlikely. The patient had no history of nephrolithiasis and urine microscopy was negative for cystine crystals. Therefore, an acquired cause was deemed more likely. Acquired causes of proximal RTA are associated to M-protein disorders, heavy metals intoxication, paroxysmal nocturnal hemoglobinuria, Sjögren's syndrome, or drug-induced (common culprits are ifosfamide, tenofovir, acetazolamide, topiramate and aminoglycosides).

Laboratory investigation showed normal blood and urinary protein electrophoresis and negative immunofixation, rendering an M-protein disorder unlikely. There was no history of sicca syndrome and immunology was negative for anti-Ro/SSA and anti-La/SSB antibodies, thus excluding the hypothesis of Sjögren's syndrome. There were no findings of hemolytic anemia to suggest paroxysmal nocturnal hemoglobinuria. Exclusion of other etiologies, rendered ifosfamide induced proximal RTA the most likely diagnosis.

Ifosfamide is an alkylating agent used in the treatment of multiple cancers such as testicular cancer and sarcomas. Active metabolites of ifosfamide, such as chloroacetaldehyde are responsible for kidney injury by inducing the inhibition enzymes of the oxidative phosphorylation pathway. ${ }^{5}$ The incidence of Fanconi syndrome following treatment is about $1.4-5 \% .{ }^{6}$ Tubular dysfunction usually presents after a median of 13 months of therapy or may have a later onset following discontinuation of therapy. ${ }^{7}$ In the case of our patient, presentation occurred 9 months after therapy initiation. In addition to tubular dysfunction, ifosfamide therapy can lead to a reduction in glomerular filtration rate. ${ }^{8}$ In most patients, the decline in GFR is mild; however in our patient presentation was more severe with a sustained $50 \%$ reduction on followup, with a current eGFR of $44.3 \mathrm{~mL} / \mathrm{min} / 1.73 \mathrm{~m}^{2}$ (CKD-EPI equation).

\section{HOW WOULD YOU MANAGE THIS CONDITION?}

Limiting additional exposure to ifosfamide is the main strategy as nephrotoxicity is cumulative and dose dependent. However, tubular dysfunction is usually persistent despite ifosfamide discontinuation. While coadministration of mesna may play a role in preventing ifosfamide associated hemorrhagic cystitis, it has no proven efficacy in preventing tubular dysfunction. ${ }^{9}$

Patients should be given bicarbonate supplements to correct acidemia as chronic acidemia predisposes the development of osteoporosis. However in proximal RTA, increasing serum bicarbonate will also increase the filtered bicarbonate load above the proximal tubule's reduced reabsorptive capacity, resulting in a marked bicarbonate diuresis. This in turn will increase urinary potassium losses, as sodium bicarbonate and water delivery to the distal tubule stimulates potassium secretion. Alkali replacement therapy can also be provided with potassium citrate, which can be helpful to prevent worsening of hypokalemia. If large doses of alkali are not tolerated or inefficient, use of a thiazide diuretic should be considered. Thiazides enhance bicarbonate reabsorption in the proximal tubule and loop of Henle by reducing the extracellular volume and provoking mild volume depletion. ${ }^{10}$ Hypokalemia may be aggravated by these drugs, and patients should be closely monitored. ${ }^{11}$

Additionally, correction hypophosphatemia will also prevent the development of osteopenia and osteoporosis. Patients may require phosphate and vitamin D supplementation to normalize the serum phosphate concentration and reverse metabolic bone disease.

Disclosure of potential conflicts of interest: none declared.

\section{References}

1. Kraut, JA, Madias, NE. Metabolic acidosis: pathophysiology, diagnosis and management. Nat Rev Nephrol 2010;6(5):274.

2. Unwin RJ, Capasso G. The renal tubular acidoses. JRSM open 2001;4(5):221-225.

3. Haque SK, Ariceta G, Batlle D. Proximal renal tubular acidosis: a not so rare disorder of multiple etiologies. Nephrol Dial Transplant 2012;27(12):4273-4287. 
4. Klootwijk ED, Reichold M, Unwin, et al. Renal Fanconi syndrome: taking a proximal look at the nephron. Nephrol Dial Transplant 2014;30(9):1456-1460.

5. Nissim I, Horyn O, Daikhin Y, et al. Ifosfamide-induced nephrotoxicity: mechanism and prevention Cancer Res 2006;66(15):7824-7831.

6. Rossi R, Pleyer J, Schafers P, et al. Development of ifosfamide-induced nephrotoxicity: prospective follow-up in 75 patients. Med Pediatr Oncol 1999;32(3):177-182.

7. Paulussen M, Craft AW, Lewis I. Results of the EICESS-92 study: two randomized trials of Ewing's sarcoma treatment-cyclophosphamide compared with ifosfamide in standard-risk patients and assessment of benefit of etoposide added to standard treatment in high-risk patients. J Clin Oncol 2008;26(27):4385-4393.

8. Oberlin O, Fawaz, O, Rey A, et al. Long-term evaluation of Ifosfamide-related nephrotoxicity in children. J Clin Oncol 2009;27(32):5350-5355.

9. Skinner R, Sharkey IM, Pearson AD, et al. Ifosfamide, mesna, and nephrotoxicity in children. J Clin Oncol 1993;11(1):173-190.
10. Rampini S, Fanconi A, Illig R, et al. Effect of hydrochlorothiazide on proximal renal tubular acidosis in a patient with idiopathic" de toni-debré-fanconi syndrome. Helv Paediatr Acta 1968; 23(1):13-21.

11. Rodenburg EM, Visser LE, Hoorn EJ, et al. Thiazides and the risk of hypokalemia in the general population. J Hypertens 2014;32(10):2092-7.

\section{Correspondence to:}

Nuno Moreira Fonseca, MD, MA.

Department of Nephrology, Centro Hospitalar Universitário de Lisboa Central, Rua da Beneficência 8, 1069-166 Lisbon, Portugal.

E-mail: nuno.mf@nyu.edu 